\title{
The Financial Impact of (Foreign) Private Investors on Team Investments and Profits in Professional Football: Empirical Evidence from the Premier League
}

\author{
Marc Rohde ${ }^{1}$, Christoph Breuer ${ }^{2}$ \\ ${ }^{1}$ German Sport University Cologne, Germany. \\ ${ }^{2}$ Institute of Sport Economics and Sport Management, German Sport University Cologne, Germany. \\ Correspondence: Marc Rohde, German Sport University Cologne, Germany.
}

Received: February 8, 2016

Accepted: March 2, 2016

Available online: March 7, 2016

doi:10.11114/aef.v3i2.1366

URL: http://dx.doi.org/10.11114/aef.v3i2.1366

\begin{abstract}
US owners at Manchester United, Arsenal London, and Liverpool; Arab owners at Manchester City; Russian owners at Chelsea London - the top football clubs from England have been acquired by private (mostly foreign) majority investors. Some of these clubs have been claimed to distort national competition, and Manchester City had to pay $€ 60 \mathrm{~m}$ as a punishment for violating UEFA Financial Fair Play rules in 2014. Thus, this article addresses the controversial financial impact of (foreign) private majority investors in the overinvestment environment of European professional football. Applying property rights theory to an unbalanced panel from the first English division from 2005/06 to 2011/12, this paper tests theoretical predictions from the 'sugar daddy' literature and empirically shows that, first, private investors increase team investment and decrease profits. And, second, the positive influence on team investment can mainly be reduced to foreign investors. Implications for utility- and profit-maximizing team owners, managers, and regulators are derived.
\end{abstract}

Keywords: Sports finance, majority investors, foreign owners, property rights theory, resource-based view, overinvestment, profitability, soccer

JEL Codes: D21, D22, D23, D92, L22, L83

\section{Introduction}

The increasing presence, spending and perceived domination of European professional football clubs owned by private majority investors are currently driving a debate on the financial impact of private owners. Industry experts have suggested that - except from a very few big global brands - money-injecting private investors are the only competitive business model of the early 21st century (Kuper, 2009). It is already the dominant financing concept in England, Eastern Europe, and parts of Italy (Franck, 2010a), and the lack of this financing concept has been suggested as the primary reason for a league's lack of international competitiveness in other countries (Barajas \& Rodriguez, 2014; Dietl \& Franck, 2007). While not explicitly citing it as an objective, there is no doubt that the introduction of the Financial Fair Play (FFP) rules in the 2013/14 season by the Union of European Football Association (UEFA) - European football's regulator - is at least partially aimed at reducing the 'overspending' or 'financial doping' by private investors (Franck, 2014; Peeters \& Szymanski, 2014).

A comparison of player salaries by clubs with domestic and foreign private owners and other clubs seems to confirm this perception. Based on 2011/12 data from Deloitte's Annual Review of Football Finance, domestic private owners pay an average salary of $€ 66 \mathrm{~m}$ per year in the Premier League. This compares to an average salary of $€ 60 \mathrm{~m}$ by clubs controlled by its member association or with distributed ownership. More strikingly, the average salary paid by foreign investors is more than double as high with $€ 137 \mathrm{~m}$.

Theoretical work has shown that private majority investors increase team investment (Franck, 2010b; Lang, Grossmann, \& Theiler, 2011; Grossmann, 2015) and raise club debts and losses (Storm \& Nielsen, 2012). They have also been suggested to be associated with a growing competitive imbalance (Franck \& Lang, 2014). Specifically, the introduction of the UEFA FFP rules has been theoretically shown to limit the spending of private investors (Sass, 2014; Madden, 2015). 
Empirical studies on the impact of private majority investors in professional sports, however, tend to be restricted to equestrian sports (Nowy et al., 2015; Smith, 2009; Wicker et al., 2012) and settings outside professional sports such as the wine industry (e.g., Frick, 2004). A notable exception is the study by Wilson et al. (2013) who compare the financial performance of English Premier League clubs that float on the stock market to clubs that are owned by domestic or foreign private investors. Using correlation analyses, ANOVA tests, and post hoc procedures, the authors determine that clubs owned by private investors are less financially efficient than clubs listed at a stock exchange. On the other hand, clubs owned by foreign private investors perform better in national leagues than public listed corporations. A main concern of the study refers to the identifiability and theoretical motivation to differentiate between clubs owned by private investors and clubs floated on the stock exchange. In fact, clubs may be listed at a stock exchange and owned by a majority investor at the same time. Sometimes, only a small part of the shares are floated. For example, the authors refer to Arsenal London as club floated on the stock exchange. While this is true, Stan Kroenke had acquired a majority share in the club by 2009. Also Manchester United is listed since August 2012, but is majority-owned by the Glazer family. On the other side, private companies may also well be owned by a number of distributed shareholders (e.g., Everton, Burnley). Thus, the authors of that study might be interested in the impact of the legal form (public listed corporation vs. private limited company) rather than the ownership structures. A further concern relates to the methodology of the study. Using ANOVA tests the study implicitly makes strong assumptions regarding normality of variables and homoscedasticity of variances. Also the study does not make use of the panel structure of the data. This is problematic due to the strong time trends in revenues, wages, and profits. Dimitropoulos and Tsagkanos (2012) conduct a fixed effects regression model to analyze the effects of different governance variables. They show that managers and / or institutional investors owning a stake in the club positively affect financial performance in European football. However, the focus of this study is rather on corporate governance quality than on the impact of private investors. To the best knowledge of the authors, no other empirical studies have analyzed the impact of private investors in professional football.

The purpose of this paper is to investigate the financial implications of private investors in English football. In order to do so, we test the impact of private investors in the first English division from 2005/06 to 2011/12 which has seen a considerable influx of private majority investors in general, and foreign majority investors specifically. To do so the authors have compiled a unique database reflecting the ownership structure of English Premier League clubs. Based on property rights theory, the authors apply a novel approach which operationalizes sugar daddies as private majority investors, thereby allowing to empirically test theoretical predictions of the sugar daddy literature (e.g., Franck, 2010b; Lang, Grossmann, \& Theiler, 2011; Storm \& Nielsen, 2012).

The rest of the paper is structured as follows: First, we provide some background information on the commercialization and internationalization of professional football in England. Second, we summarize the available literature on overinvestment in European football and theoretical literature on sugar daddies and property rights theory. Then, we explain our method before presenting the results of the analysis relating to the financial impact of (foreign) private majority investors. Next, implications for managers, regulators and owners are discussed. Finally, we provide some conclusions and recommendations for further research.

\section{Commercialization and internationalization of football in England}

In England, professional football started in the mid-19th century with the foundation of the Football Association (FA) in 1863. In 1888, the first professional European football league was established with the foundation of the Football League. As early as the late 19th century, most football clubs converted into joint stock companies (Leach \& Szymanski, 2015). Companies, local and national businessmen, and sports investors have since been able to acquire shares of English football clubs. After Tottenham Hotspurs completed the first IPO of a football club in 1983, stock exchanges experienced a boom of English football clubs going public in the 1990s. However, most public listings proved not successful, and the period of listings was followed by a period of de-listings in the 2000s (Leach \& Szymanski, 2015). In 1997, Mohamed Al Fayed acquired Fulham which made him the first foreign investor to acquire the majority share of an English football club. He was followed by Russian businessman Roman Abramovich who acquired Chelsea London in June 2003. Today, more than $90 \%$ of English Premier League and Championship clubs are owned by private majority investors. About $60 \%$ of Premier League and half of Championship club owners are not from England, with most investors originating from the United States, South-East Asia and the Middle East. Since the creation of the Premier League in 1992, English football clubs have experienced large increases in revenue, but failed to generate pre-tax profits and accumulated high debt levels (Hamil \& Walters, 2010). 


\section{Theoretical framework and literature review: Overinvestment, private owners, and property rights theory}

\subsection{Overinvestment in European professional football}

The overinvestment environment in European professional football is characterized by low profitability, wages outgrowing revenues and high debt levels. According to Deloitte's (2013) Annual Review of Football Finance, Europe's 'Big Five' football leagues are characterized by weak financial performance. Only German Bundesliga and English Premier League have been able to generate positive operating profits, while the leagues in France, Italy, and Spain have consistently generated losses during the last five years. Furthermore, according to UEFA's (2013) European Club Footballing Landscape, wage growth of European top division football clubs has consistently outpaced revenue growth for all five seasons from 2006 to 2011. However, the UEFA recognizes positive signs with clubs facing the thread of the FFP regulations. For example, revenues $(+6.9 \%)$ have outgrown wages $(+6.5 \%)$ for the first time in 2012 . Club losses have decreased for the first time in recent history from $€ 1.67 \mathrm{~b}$ in 2011 to $€ 1.07 \mathrm{~b}$ in 2012 . Also overdue payables of clubs applying for an UEFA license have decreased by $84 \%$ from 2011. Nevertheless, despite a decrease by $36 \%$, Europe's top division clubs still generated an aggregated net loss of $€ 1.1 \mathrm{~b}$ in 2012.

From a theoretical perspective, overinvestment is regularly compared to the analogs of a 'rat race' or 'arms race' and explained based on contest theory. The term 'rat race' achieved popularity thanks to a metaphor by George Akerlof who compared the wage differentials inducing people to work under harder working conditions with rats increasing their speed in their race for cheese, although no additional cheese is generated (Akerlof, 1976). Similarly, Alchian and Demsetz (1972, p. 791) referred to the inefficient overinvestment due to inter-firm competition as 'hyperactivity' or 'reverse shirking', that is, teams would invest too much effort. In contrast to the rat race, the analog of the 'arms race' of 'winner-take-all' markets argues that small differences in performance can lead to enormous differences in rewards. Frank and Cook (2010) apply this analog to sports to explain the escalating player salaries and transfer fees for the top players in European professional football.

In the context of professional sports leagues, overinvestment in playing talent has been defined from a contest-theoretical perspective as "dissipation of the league revenue [...] as a direct consequence of the ruinous competitive interaction between clubs" (Dietl, Franck, \& Lang, 2008). Thus, the concept of overinvestment explains why even clubs with profit-maximizing owners would not maximize profits at the league level (Franck, 2014). Furthermore, club owners are often not pure profit-maximizers but may rather focus on wins instead. This overinvestment problem may be increased due to regulatory measures. For example, stronger correlation between team investment and winning probability, less revenue-sharing, additional exogenous prices (e.g., due to the reform of the UEFA Champions League in 2000), an open league model, and higher revenue differentials between leagues have been attributed with increasing the overinvestment problem (Dietl, Franck, \& Lang, 2008; Franck, 2010b). Additionally, inadequate club constitutions, especially of clubs organized as non-profit businesses, have been suggested to form incentives for clubs to overinvest (Dietl \& Franck, 2000). However, given the prevalence of overinvestment by for-profit businesses, Grossmann (2015) argues that inadequate club constitutions can only partially explain overinvestment. He applies evolutionary game theory to professional sports leagues and shows that this concept can explain rat races in professional football.

The appropriateness of regulatory measures to reduce overinvestment in European football remains controversial. Müller, Lammert, and Hovemann (2012) argue that the introduction of UEFA FFP to regulate external funding is theoretically legitimized based on the attempt to sustain the integrity of the competition and to avoid negative externalities. On the other hand, Budzinski (2014) finds that from a European competition policy perspective, there are no significant financial problems due to overinvestment in European football that could justify the break-even rule of the FFP regulation.

\subsection{The financial impact of private investors}

A rapidly growing literature stream of theoretical papers studies the financial impact of money-injecting private investors which are often referred to as 'sugar daddies' or 'benefactor owners'. The literature can be broadly categorized into three domains. First, private investors have been argued to increase team investment (i.e., player salaries and net team transfer fees) which in turn drives sporting success and revenues. In a comparative analysis of governance structures, privately owned firms have been predicated to be superior in accessing funds from shareholders and investing them into the team (Franck, 2010b). Lang et al. (2011) develop a contest model of professional sports leagues to analyze the influence of private investors and argue that sugar daddies increase win percentage and revenues. In a game-theoretical analysis, Grossmann (2015) applies evolutionary game theory to sports contests and uses the concept of evolutionary stable strategies to explain higher investment levels compared to profit maximizing owners.

Second, private owners have been theoretically argued to decrease profitability (i.e., the economic return to the owner) and increase debt levels (Franck, 2010b; Grossmann, 2015; Storm \& Nielsen, 2012). Nevertheless, only a very small 
number of European football clubs have gone bankrupt. This paradox is explained through the concept of soft budget constraints which was first identified in the context of inefficient enterprises in socialist economies (Kornai, 1979). The soft budget constraints of European football clubs have been hypothesized to be positively impacted by sugar daddy owners, loose taxation, soft or interest-free loans, and infrastructure subsidies (Storm \& Nielsen, 2012).

The third research stream analyses the impact of private investors on competitive balance and social welfare, and the mitigating impact of regulations concerning the overspending of private investors. Based on contest theory, Lang et al. (2011) show that sugar daddies of large market teams decrease competitive balance and increase social welfare. Sass (2014) develops a multi-period professional team sports model to analyze the long-term influence of FFP on competitive balance. He theoretically shows that the regulatory framework reduces the overspending by sugar daddies, thereby decreasing the team's sporting success, revenues, and market size. If a sugar daddy supports a small market team, UEFA FFP actually reduces competitive balance. Madden (2015) develops a laissez-faire model of sports leagues that allows to model the impact of money injections by benefactor owners. He derives that under relatively elastic supply of talent, UEFA FFP reduces the quality of all teams, season ticket prices, fan utility, and player wages.

The contest- and game-theoretical studies of sugar daddies have in common that they take the money-injecting behavior of sugar daddies as a fact. An objective criterion to categorize owners as sugar daddies is missing. In our view, however, any empirical application to analyze the financial impact of sugar daddies requires an objective theoretical framework. This paper will build on property rights theory which is particularly suited to analyze the incentive effects and financial outcomes of different capital structures.

\subsection{Ownership and Property Rights}

Despite the extensive theoretical literature on the impact of sugar daddies, no empirical papers have tested the results derived. An obvious reason is the subjective categorization of sugar daddies. The current paper addresses this challenge by operationalizing sugar daddies based on property rights theory. Property rights theory assumes that a company is mainly characterized by three fundamental rights: residual control, residual claim, and transfer right (Alchian, 1977; Demsetz, 1967; Milgrom \& Roberts, 1992). The theory assumes that each individual maximizes his utility, and takes into consideration that the underlying contracts and their monitoring create transaction costs. In contrast to Coase's (1960) renowned article on the problem of social cost which claims that property rights ownership would not affect the allocation of resources and the efficiency of the firm, later scholars have challenged this view based on positive or negative incentive effects related to property rights (Alchian \& Demsetz, 1972). From a property rights perspective, concentrated ownership by private companies has been determined to be beneficial, since all rights are concentrated with the owner which implies the highest economic efficiency and the lowest welfare loss (Demsetz, 1967, pp. 354-355; Picot, 1981).

With respect to sports management, theoretical and empirical studies have applied property rights theory to analyze the impact of ownership on the sporting and financial success of clubs. In this respect, ownership by member associations has been theoretically shown to benefit sponsoring revenues of professional football clubs (Dietl \& Weingärtner, 2011). Furthermore, supporter trusts have been shown to positively impact profitability and negatively impact national league success in English Championship (Ruoss, 2009, pp. 138-143). Thus, this paper follows property rights theory and operationalizes ownership trough a dummy variable accounting for majority shareholders controlling all property rights. ${ }^{1}$

To sum up, we have presented theory and literature consistently claiming a positive impact of money-injecting private investors ('sugar daddies') on investments, and a negative impact on profitability. We have further operationalized these investors based on property rights theory as private majority investors.

Hypothesis 1: Private majority investors cause higher team investments and lower profits [€m].

\subsection{Foreign investors, resource-based view, and overinvestment}

The entry of foreign investors is a newer and less analyzed phenomenon than the entry of private investors in general. Given the two mega trends of commercialization and internationalization in English and European football, this is quite surprising. One potential reason for the lack of empirical studies might be the lack of transparency on the ownership structures in English football. The authors of this paper have brought together a unique database covering owner shareholdings in the English Premier League from 2005/06 onwards. A second reason may be of theoretical nature, since the nationality of owners in itself does not yet motivate a theoretical discrimination on their financial impact. This paper uses an indirect approach by building on the resource-based view in combination with the overinvestment environment in European football to motivate the analysis of the financial impact of foreign investors. That is, the nationality of investors here may be seen as a proxy for the private wealth of investors in the absence of reliable panel

\footnotetext{
${ }^{1}$ In fact, this definition of majority shareholders being able to exercise control or influence in the club is also of high practical relevance. For example, the UEFA has adopted this definition for their regulation on multi-club ownership as early as the $2009 / 10$ season.
} 
data on investor resources. Also, the discussion of objective functions in Europe and abroad is of relevance.

The resource-based view assumes that a firm's competitive advantage is based on its resources and the efficiency with which these resources are utilized (Wernerfelt, 1984). In a context of sport management, the inequality of resources by owners or sponsors has been argued to impact the financial and / or sporting success of sponsoring relationships (Amis et al., 1997), university sports programs (Smart \& Wolfe, 2000), basketball teams (Berman et al., 2002), and baseball teams (Smart \& Wolfe, 2003). ${ }^{2}$ Drawing on resource dependency theory, the scarcity of resources has also been shown to be an issue in German non-profit sports clubs (Wicker \& Breuer, 2011). Gerrard (2005) develops a resource-utilization model for professional sports teams, and finds that the financial performance of teams is significantly affected by their ownership status.

In the 2014/15 season, those teams with the lowest spending power in the English Premier League had predominantly English owners with distributed shareholders (Table 1). According to Forbes, those five teams with the major shareholders' net worth below \$100m include four English and one Welsh owner. Everton's, Swansea's, and West Bromwich's wages even exceed their owners' net wealth. That is, those owners could not even cover one year's club wages, so that the teams cannot expect significant injections of their owners' pockets. On the other end, only two of the twelve billionaire majority owners are English. Despite Manchester City’s leading wage costs of \$343m, its owner Sheikh Mansour bin Zayed Al Nahyan would be able to pay the club's wages for more than eighty seasons out of his pocket.

Table 1. Estimated spending power of English Premier League owners in 2014/15 season.

\begin{tabular}{|c|c|c|c|c|c|}
\hline Club & Major Shareholder & Origin & Net wealth $(\$ \mathrm{~m})^{2}$ & Wages $(\$ m)^{3}$ & $\begin{array}{l}\text { Wages / net } \\
\text { wealth }\end{array}$ \\
\hline Everton & Bill Kenwright $\mathrm{CBE}^{1}$ & England & 50 & 93 & $185 \%$ \\
\hline Swansea City & Mr. \& Mrs. Martin Morgan ${ }^{1}$ & Wales & 47 & 72 & $152 \%$ \\
\hline West Bromwich Albion & Jeremy Peace & England & 60 & 79 & $132 \%$ \\
\hline Crystal Palace & Steve Parish $^{1}$ & England & 67 & 28 & $41 \%$ \\
\hline Burnley & Mike Garlick $^{1}$ & England & 82 & 23 & $28 \%$ \\
\hline Queens Park Rangers & Tony Fernandes & Malaysia & 615 & 115 & $19 \%$ \\
\hline West Ham United & David Sullivan & Wales & 595 & 83 & $14 \%$ \\
\hline Liverpool & John W. Henry & US & 1,620 & 195 & $12 \%$ \\
\hline Aston Villa & Randy Lerner & US & 1,000 & 109 & $11 \%$ \\
\hline Sunderland & Ellis Short & US & 1,360 & 85 & $6 \%$ \\
\hline Manchester United & The Glazer Family & US & 4,400 & 269 & $6 \%$ \\
\hline Hull City & The Allam Family & Egypt & 982 & 38 & $4 \%$ \\
\hline Stoke City & The Coates Family & England & 2,400 & 89 & $4 \%$ \\
\hline Arsenal & E. Stanley Kroenke & US & 6,300 & 227 & $4 \%$ \\
\hline Chelsea & Roman Abramovich & Russia & 8,900 & 262 & $3 \%$ \\
\hline Tottenham Hotspur & Joe Lewis & England & 5,500 & 141 & $3 \%$ \\
\hline Southampton & Katharina Liebherr & Switzerland & 3,500 & 69 & $2 \%$ \\
\hline Newcastle United & Mike Ashley & England & 4,900 & 91 & $2 \%$ \\
\hline Leicester City & Srivaddhanaprabha Family & Thailand & 2,600 & 38 & $1 \%$ \\
\hline Manchester City & Mansour bin Zayed Al Nahyan & UAE & 29,700 & 343 & $1 \%$ \\
\hline
\end{tabular}

Notes: Estimates refer to estimated net wealth of largest shareholder only; in the absence of 2014/15 data, figures refer to most up-to-date figures; corr(net worth, wages) $=0.75$; (1) Minority shareholder; Sources: (2) Forbes (2012), Forbes (2015); (3) Deloitte (2014)

On an aggregated level, the estimated wealth of foreign majority investors in the English Premier League clearly exceeds those of domestic investors (Table 2). The largest shareholders of clubs with distributed ownership are estimated to have a net wealth of $\$ 0.06 \mathrm{~b}$ at their disposal. This compares to $\$ 3.2 \mathrm{~b}$ by domestic majority investors and $\$ 5.1 \mathrm{~b}$ by foreign majority owners. More strikingly, the relative wages of foreign majority owners are estimated to be only $7 \%$ of their owners' personal net wealth - one fifth of that of domestic majority owners (35\%) and a small fraction of that of clubs with minority owners $(102 \%)$. These figures clearly show supreme resources in form of private net wealth by foreign owners which benefits clubs in the overinvestment environment of European professional football.

\footnotetext{
${ }^{2}$ See also Gerrard (2003) for a good and extensive literature review on the application of the resource-based view in sport management.
} 
Foreign owners also seem to be less bound to budget constraints than domestic owners. ${ }^{3}$

Table 2. Absolute and relative spending power by ownership type in English Premier League.

\begin{tabular}{|c|c|c|c|}
\hline Ownership type & Count & Avg. net wealth $(\$ \mathrm{~m})$ & Avg. wages / net wealth \\
\hline Distributed ownership & 4 & 62 & $102 \%$ \\
\hline Domestic majority owners & 4 & 3.215 & $35 \%$ \\
\hline Foreign majority owners & 12 & 5.131 & $7 \%$ \\
\hline
\end{tabular}

Sources: Forbes (2012), Forbes (2015); Deloitte (2014); Author calculations

In addition to their superior spending power and the de-facto absence of budget constraints, foreign owners may also generate superior utility. Demsetz (1967, p. 350) suggested that takeovers by new owners are regularly motivated by new owners recognizing new cost-benefit opportunities. On the one hand, a small number of foreign investors - mostly from the US - have been suggested to be profit maximizers (Nauright \& Ramfjord, 2010). For example, the Glazers as owners of Manchester United are often cited as example (Hamil, 2008). On the other hand, English teams have been found to be closer to win than to profit maximization (Garcia-del-Barrio \& Szymanski, 2009). Given the overinvestment environment of European football, the entry of foreign owners is regularly motivated by superior power and reputation, geo-political benefits, and multi-ownership synergies. For example, many Asian investors turn to European football due to the absence of competitive domestic leagues, the ability to acquire knowledge about training and organization, and reputation gained from owning premium European clubs (Hansen et al., 2011). Several US investors such as Arsenal London's Stan Kroenke own a range of further clubs which allows them to generate multi-ownership synergies. Finally, state-owned investors from the Middle East have been suggested to follow geo-political interests. For example, Qatar has linked their acquisition of football clubs (e.g., Paris Saint-Germain) with the expansion of its TV station Al Jazeera in Europe - most prominently through its French affiliate BeIN.

Given the quantity (16 out of 20) and superior spending power of foreign private investors in the English Premier League, it is surprising that no empirical, causational study has studied the financial impact of foreign private majority investors. This study aims to close this research gap, and provide insights to (potential) owners, managers, and regulators on the impact of this increasingly prevalent financing model.

Hypothesis 2: Foreign private majority investors cause higher team investments and lower profits [€m].

\section{Methodology}

\subsection{Data source and collection}

Sample and generalizability. This paper uses an unbalanced panel of English Premier League clubs from 2005/06 to 2011/12. ${ }^{4}$ The full sample includes $n=140$ observations (32 clubs, 7 seasons). As discussed above, the Premier League is characterized by significant within-variation with respect to the entry of domestic and foreign private majority investors. While English top professional football is subject to some peculiarities like the advanced commercialization and internationalization, we consider the results largely generalizable to other professional leagues facing the entry of domestic or foreign majority investors.

Data sources. Financial data including wages and profits have been sourced from publicly available databases. English club data are published in Deloitte's "Annual Review of Football Finance". Information on the ownership structure have been collected from a variety of reliable sources such as The Guardian, Forbes, and clubs' annual reports and homepages.

\subsection{Measures}

Table 3 provides an overview of the variables used in this paper. Team investments are more accurately reflected by wages than by transfer fees for several reasons. First, wages can be drawn from official figures while transfer fee data may vary widely. Second, wages are able to account for home-grown players. Third, wages may better reflect changing player productivity over time (Szymanski, 2013). Thus, team investments will be measured by wage expenses including social security payments. Consistent with existing literature, team wages including social security payments (LOGWAG) are logarithmized to account for the right-skewed distribution of the variable (Mincer, 1974; Peeters \& Szymanski, 2014). Profitability may be measured in several ways including net profits, operating profits before and after interests, taxes and player trading activity. In this article profits are measured as operating profit before player trading activity, firstly because it accurately reflects the annual economic return, and secondly because player transfer fees would represent distorting fluctuations (Deloitte, 2013). Operating profits are better fit by quadratic than linear distributions,

\footnotetext{
${ }^{3}$ The main shareholder's net worth and team wages of Premier League teams in 2013/14 strongly correlate with a correlation factor of 0.75 .

${ }^{4}$ Ownership data could be reliably traced back until the 2005/06 season.
} 
and are thus also logarithmized (LOGPRO) to more closely satisfy the assumptions of the classical linear panel data model (Wooldridge, 2012, pp. 192-193).

Table 3. Overview of Variables.

\begin{tabular}{llll}
\hline Variable type & Variable & Description & Scale \\
\hline IDs & clubid2 & Club ID & Metric \\
\hline Dependent variables & logwag & $\begin{array}{l}\text { Log of wage expenses incl. social security } \\
\text { payments }(€ m) \\
\text { Log of operating profit before player trading } \\
\text { activity }(€ \mathrm{~m})\end{array}$ & Metric \\
\hline Independent variables & inv & $\begin{array}{l}\text { Dominating private investor with }>50 \% \text { share } \\
(1=\text { yes, } 0=\text { no) }\end{array}$ & Dummy \\
& Foreign majority investor (1=yes, $0=$ no) & Dummy \\
\hline Control variables & tifl_rel & Time in 1st league since 1993 - pre season (\%) & Metric \\
& squad_age & Average age of squad (\# years) & Metric \\
& sta_cap & Stadium capacity ('000) & Metric
\end{tabular}

Based on property rights theory, the independent variables are defined as follows. INV is a dummy variable for private majority investors with a share in excess of 50\%, and INV_FOR is a dummy variable for foreign private majority investors. For both the wage model and profit model we control for club and time fixed effects. This way we can control for the impact of team quality, history, market size and other club-specific or time-dependent changes on wages and / or profits. According to human capital theory, wages are expected to be impacted by changing squad characteristics such as the average age of the squad (Szymanski, 2013). SQUAD_AGE measures the average age per club and year, and is expected to have a positive impact on wages due to additional player experience and reduced uncertainty by the club about the player quality. Also wages may be influenced by changing spending powers of clubs as a consequence of repeatedly benefiting from being part of the first division (Nadeau \& O'Reilly, 2006). Most notably, these advantages include higher broadcasting revenues. This effect is controlled for by TIFL_REL which measures the relative time of the club in the first league since introduction of the Premier League in 1993. Finally, changes in club profits may be impacted by changes in stadium capacity. STA_CAP measures the stadium capacity per club and year, and is expected to have a positive influence on profits.

\subsection{Data analysis}

The data analysis is structured as follows. First, descriptive statistics including mean, variance, minimum and maximum will be presented for all variables. Next, the within variation in the ownership structure during the observation period will be presented. Then, regression analyses will be conducted to analyze the financial impact of private majority investors in general and foreign majority investors specifically. In total, four regression models will be performed to determine the impact of (1) private majority investors and (2) foreign majority investors on (a) wages and (b) operating profits. Variables have been checked for non-linearity, and wages and profits are log-transformed to account for the right-skewness of the variables. Also the applicability of random effects models has been tested using the Hausman test and the Schaffer and Stillman test. For both tests, the null hypothesis of no systemically different results between fixed and random effects models is rejected, that is, the tests favor a fixed effects model. An additional advantage of the fixed effects model is to make use of the within variation in the ownership structure of clubs. Furthermore we formally tested for potential heteroscedasticity in the data by performing Levene's robustness test for the equality of variances between groups. The results show that heteroscedasticity exists with respect to clubs. Since we also need to account for time trends, a two-way fixed effects panel data model with robust (Huber / White) standard errors is performed. The following regression equations are applied:

$$
\begin{aligned}
& \text { LOGWAG }_{i t}=\beta_{0}+\beta_{1} \mathrm{INV}_{i t}+\beta_{2} \text { INV_FOR }_{i t}+\beta_{3} \text { TIFL_REL }_{i t}+\beta_{4} \text { SQUAD_AGE }_{i t}+\beta_{5} \text { Year }_{i t}+\varepsilon_{i t}, \\
& \text { LOGPRO }_{i t}=\beta_{0}+\beta_{1} \text { INV }_{i t}+\beta_{2} \text { INV_FOR }_{i t}+\beta_{3} \text { STA_CAP }_{i t}+\beta_{4} \text { Year }_{i t}+\varepsilon_{i t},
\end{aligned}
$$

whereby $\mathrm{i}=1, \ldots, 32$ indexes club and $\mathrm{t}=2006, \ldots, 2012$ indexes year.

One potential issue with the data is multicollinearity. Private investors may choose to invest in teams with strong histories. However, correlation coefficients between relative time in first league and private majority investors (0.16) or foreign private majority investors $(0.23)$ are rather small. Also variance inflation factors are low (i.e., smaller than ten) and regressions did not show significant results. 


\section{Results}

\subsection{Descriptive statistics}

The summary statistics for all variables in the model are displayed in Table 4. On average, clubs paid wages of $€ 81.7 \mathrm{~m}$ and generated operating profits of $€ 7.0 \mathrm{~m}$ per season. The highest operating loss was generated by Manchester City with $€ 94.1 \mathrm{~m}$. In contrast, the highest operating profit was achieved by Portsmouth in 2010 with $€ 116.0 \mathrm{~m}$, partly thanks to a net transfer income of more than $€ 40 \mathrm{~m}$. About $85 \%$ of observations refer to clubs with private majority investors, and nearly half of all observations (44\%) refer to clubs with foreign private majority investors. On average, teams have spent $64 \%$ of previous seasons in the first national division. The average age of squads amounts to 24.8 years. Stadium capacities vary between 17,340 (Blackpool) and 76,210 people (Manchester United), with an average of 38,040 people.

Table 4. Summary statistics.

\begin{tabular}{llccccc}
\hline Variable type & Variable & $\mathrm{N}$ & Mean & Std. Dev. & Min & Max \\
\hline IDs & clubid2 & 140 & 119.93 & 62.66 & 1 & 32 \\
\hline Dependent variables & wag & 138 & 81.72 & 57.68 & 25.45 & 457.11 \\
& pro & 137 & 7.03 & 30.14 & -94.06 & 116.01 \\
\hline \multirow{2}{*}{ Independent variables } & inv & 140 & 0.85 & - & 0 & 1 \\
& inv_for & 140 & 0.44 & - & 0 & 1 \\
\hline Control variables & tifl_rel & 140 & 0.64 & 0.36 & 0 & 1 \\
& squad_age & 140 & 24.77 & 1.20 & 21.3 & 27.9 \\
& sta_cap & 140 & 38.04 & 13.37 & 17.34 & 76.21 \\
\hline $\mathrm{N}$ & & & & & \\
\hline
\end{tabular}

\subsection{Within Variation}

The within variation of in the ownership structure in England and France from 2006 to 2012 is summarized in Figure 1. The number of private majority investors has increased from 14 in 2006 to 18 in 2012. During the same period, the number of foreign majority investors has more than doubled from four in 2006 to ten in 2012. Additionally, transition probabilities have been determined to better understand changes in ownership structure over time. We find that four observations $(25 \%)$ referring to clubs with initially distributed ownership $(n=16)$ feature a takeover by a dominating private investor (Arsenal, Aston Villa, Manchester City, Newcastle United), whereby Newcastle United is the only club being acquired by a domestic majority investor. Six observations $(11.1 \%)$ referring to clubs with initially domestic ownership $(\mathrm{n}=54)$ feature a takeover by a foreign majority investor (Arsenal, Aston Villa, Blackburn, Manchester City, Portsmouth, West Ham). No transitions from foreign to domestic owners of from private majority owners to distributed ownership have taken place in the sample. A range of further changes in ownership has taken place, but refers to the same type of investor.

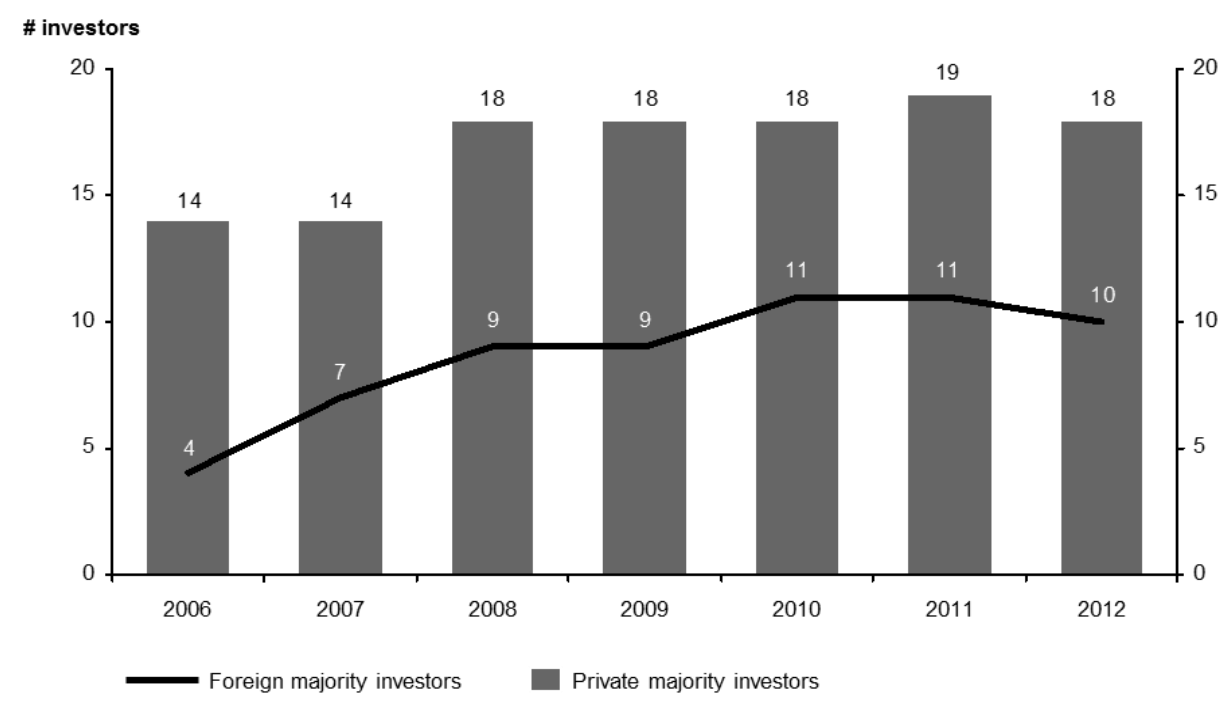

Figure 1. Changes in ownership structure in English Premier League from 2006 to 2012. 


\subsection{Panel Regression}

In the following we will present the results of the two-way fixed effects panel regression with time and club fixed effects for the impact of (foreign) private majority investors on wages and profits (Table 5). Firstly, the wage model without controlling for foreign investors shows a significant positive impact at the $5 \%$ level of private majority investors on wages. On average, clubs which have been taken over by a private majority investor pay salaries which are about $21 \%$ higher. $^{5}$ The coefficients of the control variables are consistent with expectations. Clubs' aggregated times in the first league have a positive impact on wages, and the time dummies have a positive and increasing impact relative to the reference year of 2006. When adding the foreign investor variable, however, the positive impact of private majority investors turns insignificant. Instead, foreign investors have a positive and significant impact on wages at the 5\% level. The explanatory power of both wage models is fairly high with R-square values above 0.5 . This confirms both research hypotheses with respect to wages.

The profit model without foreign investors shows a negative impact of private majority investors on profits which is significant at the 5\% level, while stadium capacity has the expected positive impact on profits. On average, clubs which have been taken over by a private majority investor generate profits which are about $10 \%$ lower. When adding the foreign investor variable, the impact of private majority investors turns insignificant, while foreign majority investors have a negative and weakly significant impact at the $10 \%$ level. The explanatory power of the profit models are lower with $\mathrm{R}$-square values above 0.20 . However, this has been expected due to the revenue and wage effects partially cancelling each other out.

To sum up, our regression results support both of our hypotheses that private majority investors in general and foreign private majority investors specifically pay higher wages, but create lower profits than clubs with distributed ownership.

Table 5. Key regression results: Impact of (foreign) majority investors on wages and profit

\begin{tabular}{|c|c|c|c|c|}
\hline \multirow{2}{*}{$\begin{array}{l}\text { MODEL } \\
\text { inv }\end{array}$} & \multicolumn{2}{|c|}{ LOGWAG } & \multicolumn{2}{|c|}{ LOGPRO } \\
\hline & $0.1914 *$ & 0.0784 & $-0.1087 *$ & -0.0791 \\
\hline & $(0.0911)$ & $(0.1034)$ & $(0.0506)$ & $(0.0467)$ \\
\hline \multirow[t]{2}{*}{ inv_for } & & $0.1840^{*}$ & & $-0.0496(*)$ \\
\hline & & $(0.0846)$ & & $(0.0263)$ \\
\hline \multirow[t]{2}{*}{ tifl_rel } & $1.8897 * * *$ & $1.7581 * * *$ & & \\
\hline & $(0.5183)$ & $(0.5122)$ & & \\
\hline \multirow[t]{2}{*}{ squad_age } & 0.0355 & 0.0271 & & \\
\hline & $(0.0252)$ & $(0.0251)$ & & \\
\hline \multirow[t]{2}{*}{ sta_cap } & & & $0.0113 * * *$ & $0.0111 * * *$ \\
\hline & & & $(0.0022)$ & $(0.0020)$ \\
\hline \multirow[t]{2}{*}{$\mathrm{y} 2$} & $0.1813 * *$ & $0.1440 *$ & $-0.0279(*)$ & -0.0180 \\
\hline & $(0.0653)$ & $(0.0663)$ & $(0.0161)$ & $(0.0154)$ \\
\hline \multirow[t]{2}{*}{$\mathrm{y} 3$} & $0.1463 *$ & 0.1136 & -0.0013 & 0.0076 \\
\hline & $(0.0696)$ & $(0.0699)$ & $(0.0203)$ & $(0.0202)$ \\
\hline \multirow[t]{2}{*}{ y4 } & $0.1221(*)$ & 0.0858 & $-0.0343 *$ & -0.0237 \\
\hline & $(0.0698)$ & $(0.0705)$ & $(0.0167)$ & $(0.0146)$ \\
\hline \multirow[t]{2}{*}{ y5 } & $0.2313 * *$ & $0.1862 *$ & $-0.0422(*)$ & -0.0289 \\
\hline & $(0.0757)$ & $(0.0771)$ & $(-0.0210)$ & $(0.0212)$ \\
\hline \multirow[t]{2}{*}{ y6 } & $0.2963 * * *$ & $0.2465 * *$ & $-0.0563(*)$ & -0.0412 \\
\hline & $(0.0776)$ & $(0.0795)$ & $(0.0311)$ & $(0.0334)$ \\
\hline \multirow[t]{2}{*}{ y7 } & $0.3599 * * *$ & $0.3204 * * *$ & -0.0322 & -0.0184 \\
\hline & $(0.0830)$ & $(0.0834)$ & $(0.0216)$ & $(0.0234)$ \\
\hline Club fixed effects & Yes & Yes & Yes & Yes \\
\hline \multirow[t]{2}{*}{ Constant } & $1.7803^{*}$ & $2.1231 * *$ & $5.0312 * * *$ & $5.0254 * * *$ \\
\hline & $(0.7444)$ & $(0.7472)$ & $(0.0618)$ & $(0.0551)$ \\
\hline Observations & 138 & 138 & 137 & 137 \\
\hline R-squared & 0.5367 & 0.5585 & 0.2327 & 0.2509 \\
\hline \# of clubid & 32 & 32 & 32 & 32 \\
\hline
\end{tabular}

Note: Std. Err. in parentheses: $* * * \mathrm{p}<0.001,{ }^{* *} \mathrm{p}<0.01,{ }^{*} \mathrm{p}<0.05,{ }^{(+)} \mathrm{p}<0.1$

\footnotetext{
${ }^{5}$ The relative impact of a takeover by private majority investors amounts to $\left(\mathrm{e}^{\wedge} 0.1914-1\right) * 100 \%=21 \%$.
} 


\section{Discussion}

Using an unbalanced sample of English Premier League clubs, our empirical analysis has provided evidence that private majority investors in general and foreign private majority investors specifically pay higher wages and generate lower profits than clubs with distributed ownership. Also, we found that the impact of private majority investors can mostly be reduced to foreign private majority investors. These findings suggest that, first, concentrated property rights by owners are able to explain higher team investments and lower club profitability, and, second, the resource-based view in combination with the overinvestment environment in European professional football is able to explain the increased impact of foreign investors compared to domestic investors on wages.

The empirical results support the theoretical models predicting the impact of sugar daddies on team investment and profitability (e.g., Franck, 2010a; Lang, Grossmann, \& Theiler, 2011; Storm \& Nielsen, 2012). As an extension to this literature, our paper has used the measurable and meaningful construct of private majority ownership to operationalize sugar daddies. Thus, our research contributes by shedding light on the black box of the motivation of sugar daddies. Specifically, our results have shown that owner incentives and rights are able to explain the extent of team investments and profitability.

With respect to foreign investors, our research extends the growing research stream applying the resource-based view on sport management (e.g., Gerrard, 2005; Smart \& Wolfe, 2000). In line with Gerrard (2005) our results show that ownership status affects the financial performance of teams. While Gerrard (2005) suggested that stock market listing improves financial performance, these results remain controversial and later studies have suggested that the impact of stock exchange listings may be a one-off or short-term effect (Baur \& McKeating, 2011; Leach \& Szymanski, 2015). In contrast, this research links the ownership status to the less diminishing stock of the owner's private wealth and suggests that superior private wealth is a key reason for the continuous entry of foreign investors in the English Premier League.

Foreign private investor coefficients have a higher magnitude than the general private investor dummies for the wage model, but a lower one for the profitability model. This might be explained by a peculiarity identified by Nauright and Ramfjord (2010). They argued that foreign investors in the English league system are more profit-oriented than domestic owners. While our empirical results show that foreign owners still have a significantly negative impact on profits, the lower size of the coefficient may be referred to this attitude.

As discussed before, the phenomenon of foreign investors acquiring professional football clubs is not limited to the Premier League, but is also already very common in Eastern Europe, parts of Italy, and lower-tier English divisions (Franck, 2010a). Also in other leagues including France, Germany, and Spain, first clubs have been acquired by foreign investors. While every league is subject to different regulations and production technologies, the authors expect the results to be generalizable to European professional football. Thus, our results strengthen the argument by previous scholars suggesting a positive impact of wealthy, foreign investors on a league's international competitiveness (Barajas \& Rodriguez, 2014; Dietl \& Franck, 2007). Based on the mitigating impact of UEFA's FFP on overspending (Sass, 2014), the size of the effect of (foreign) private investors may be expected to decrease in the future.

\section{Conclusion}

\subsection{Managerial implications}

The results presented have several implications for both managers and regulators in European football. It needs to be differentiated between utility- or win-maximizing and profit-maximizing stakeholders. First, utility-maximizing managers and regulators are well advised to encourage the entry of private investors in general and foreign private investors specifically. It has been shown that (foreign) private majority investors drive team investments. This behavior has been explained based on the incentive structure and the available resources of team owners. Second, however, profit-maximizing (or 'loss-minimizing') managers and regulators are well advised to either prevent the entry of (foreign) private investors - a procedure principally implemented through the German ' $50+1$ rule' - or limit team investments by owners - a procedure principally enforced through UEFA's FFP rules.

Current or aspiring owners of professional football clubs are well advised to thoroughly evaluate their investment decisions. Ownership structure, private wealth and owner incentives determine investment decisions and the competitiveness of a club relative to its competitors. First, clubs owned by a private majority investor have superior incentives to invest into the team compared to shareholders of clubs with distributed ownership. Second, acquiring a majority share rather than a minority share regularly goes in line with strategic decision authority. Third, owners should be aware of their own spending power relative to its direct competitors. Given the rapidly escalating wages, only investors with 'deep pockets' are likely to support their team sustainably. Similarly, investors should be aware of their incentive structure and those of its competing owners. 


\subsection{Limitations \& recommendations for further research}

This paper has a few limitations that might be addressed by further research. First, as this was the first empirical study to analyze the financial impact of private majority investors, further studies are recommended to confirm the results and further specify the managerial and policy interventions. Specifically, it would be helpful to extend the research to further samples with significant variation in ownership structure. For example, sugar daddies have been argued to be an important phenomenon in professional football in Italy and Eastern Europe. Also, amateur sports have been suggested to be impacted by the entry of sugar daddies. Furthermore, the availability of future financial data will allow analyzing the impact of the UEFA FFP rules. Second, this study has analyzed the impact of private investors on two financial variables: wages and profitability. Future studies may aim to differentiate the direct and indirect impact of private investors on wages, new revenue streams, and further monetary and non-monetary variables. A third limitation of this study is related to the objective function of foreign investors in England. This paper has suggested that there is a balancing impact of incentives and resources driving team investments and lowering profits on the one hand, and more profit-maximizing behavior by foreign owners on the other hand. Future studies may address this suggestion in more detail. Also foreign investors from the US, Middle East, Russia and other regions may have different objective functions based on different time horizons, investment policies and degrees of risk aversion. Comparative studies may analyze the impact of owner nationality on investment behavior and profit maximization in more detail.

\section{References}

Akerlof, G. (1976). The Economics of Caste and of the Rat Race and Other Woeful Tales. The Quarterly Journal of Economics, 90(4), 599-617. http://dx.doi.org/10.2307/1885324

Alchian, A. A. (1977). Some Economics of Property Rights. In A. A. Alchian (Ed.), Economic Forces at Work, 127149. Indianapolis: Liberty Press.

Alchian, A. A., \& Demsetz, H. (1972). Production, Information Costs, and Economic Organization. The American Economic Review, 62(5), 777-795. Retrieved from http://www.jstor.org/stable/1815199

Amis, J., Pant, N., \& Slack, T. (1997). Achieving a sustainable competitive advantage: a resource-based view of sport sponsorship. Journal of Sport Management, 11(1), 80-96. Retrieved from http://journals.humankinetics.com/jsm-back-issues/JSMVolume11Issue1January/AchievingaSustainableCompetiti veAdvantageAResourceBasedViewofSportSponsorship

Barajas, Á., \& Rodriguez, P. (2010). Spanish Football Clubs' Finances: Crisis and Player Salaries. International Journal of Sport Finance, 5(1), 52-66. Retrieved from http://fitpublishing.com/content/spanish-football-clubs-finances-risis-and-player-salaries-pp-52-66

Barajas, A., \& Rodriguez, P. (2014). Spanish Football in Need of Financial Therapy: Cut Expenses and Inject Capital. International Journal of Sport Finance, 9(1), 73-90. Retrieved from http://fitpublishing.com/articles/spanish-football-need-financial-therapy-cut-expenses-and-inject-capital

Baur, D. G., \& McKeating, C. (2011). Do Football Clubs Benefit from Initial Public Offerings? International Journal of Sport Finance, $6(1), \quad 40-59 . \quad$ Retrieved http://fitpublishing.com/content/do-football-clubs-benefit-initial-public-offerings

Berman, S. L., Down, J., \& Hill, C. W. L. (2002). Tacit Knowledge as a Source of Competitive Advantage in the National Basketball Association. Academy of Management Journal, 45(1), 13-31. http://dx.doi.org/10.2307/3069282

Budzinski, O. (2014). The Competition Economics of Financial Fair Play. In O. Budzinski \& A. Feddersen (Eds.), Political Economics. Competition and Regulation: Vol. 14. Contemporary Research in Sports Economics: Proceedings of the 5th ESEA Conference. Frankfurt (Main): Peter Lang. Retrieved from http://ssrn.com/abstract=2409632

Coase, R. H. (1960). The Problem of Social Cost. Journal of Law \& Economics, 3, 1-44. Retrieved from http://heinonline.org/HOL/Page?handle=hein.journals/jlecono3\&id=1\&div=\&collection=

Deloitte (2013). Annual Review of Football Finance: Turn on, tune in, turnover. Manchester, UK.

Demsetz, H. (1967). Toward a Theory of Property Rights. The American Economic Review, 57(2), 347-359.

Dietl, H. M., \& Franck, E. (2000). Effizienzprobleme in Sportligen mit gewinnmaximierenden Kapitalgesellschaften eine modelltheoretische Untersuchung. Zeitschrift für Betriebswirtschaft, 70(10), 1157-1175.

Dietl, H. M., \& Franck, E. (2007). Governance Failure and Financial Crisis in German Football. Journal of Sports Economics, 8(6), 662-669. http://dx.doi.org/10.1177/1527002506297022 
Dietl, H. M., \& Weingaertner, C. (2011). The effect of professional football clubs' legal structure on sponsoring revenue. Journal of Sponsorship, 4(4), 377-390. http://dx.doi.org/10.2139/ssrn.2493130

Dietl, H. M., Franck, E., \& Lang, M. (2008). Overinvestment in Team Sports Leagues: A Contest Theory Model. Scottish Journal of Political Economy, 55(3), 353-368. http://dx.doi.org/10.1111/j.1467-9485.2008.00457.x

Fama, E. F. (1980). Agency Problems and the Theory of the Firm. The journal of political economy, 88(2), 288-307. http://dx.doi.org/10.1086/260866

Franck, E. (2010). Private Firm, Public Corporation or Member's Association Governance Structures in European Football. International Journal of Sport Finance, 5(2), 108-127. Retrieved from http://fitpublishing.com/content/private-firm-public-corporation-or-member\%E2\%80\%99s-association-governance -structures-european

Franck, E. (2010). Zombierennen“ und Patenonkel“ - Warum deutsche Fussballklubs in der Champions League den Kürzeren ziehen. CRSA Working Paper, 36, 1-13.

Franck, E. (2014). Financial Fair Play in European Club Football - What is it all about? UZH Business Working Paper Series, April 2014 (Working Paper No. 328), 1-34. Retrieved from ftp://ftp.repec.org/opt/ReDIF/RePEc/zrh/wpaper/328_IBW_full.pdf

Franck, E., \& Lang, M. (2014). A Theoretical Analysis of the Influence of Money Injections on Risk Taking in Football Clubs. Scottish Journal of Political Economy, 61(4), 430-454. http://dx.doi.org/10.1111/sjpe.12052

Frick, B. (2004). Die Voraussetzungen sportlichen und wirtschaftlichen Erfolges in der Fußball-Bundesliga. In M. Bieling, M. Eschweiler, \& J. Hardenacke (Eds.), Business-to-Business-Marketing im Profifußball , 71-93. Wiesbaden: Deutscher Universitätsverlag. http://dx.doi.org/10.1007/978-3-322-81649-8_4

Garcia-del-Barrio, P., \& Szymanski, S. (2009). Goal! Profit Maximization Versus Win Maximization in Soccer. Review of Industrial Organization, 34(1), 45-68. http://dx.doi.org/10.1007/s11151-009-9203-6

Gerrard, B. (2003). What does the resource-based view "bring to the table" in sport management research? European Sport Management Quarterly, 3(3), 139-144. http://dx.doi.org/10.1080/16184740308721947

Gerrard, B. (2005). A resource-utilization model of organizational efficiency in professional sports teams. Journal of Sport Management, 19(2), 143-169. Retrieved from http://journals.humankinetics.com/AcuCustom/Sitename/Documents/DocumentItem/4724.pdf

Grossmann, M. (2015). Evolutionarily Stable Strategies in Sports Contests. Journal of Sports Economics. 16(1), 108-121. http://dx.doi.org/10.1177/1527002512470957

Hamil, S. (2008). Case 9: Manchester United: the Commercial Development of a Global Football Brand. In S. Chadwick \& D. Arth (Eds.), International Cases in the Business of Sport (pp. 114-134). Oxford: Butterworth-Heinemann. http://dx.doi.org/10.1016/B978-0-7506-8543-6.50014-7

Hamil, S., \& Walters, G. (2010). Financial performance in English professional football: 'an inconvenient truth'. Soccer \& Society, 11(4), 354-372. http://dx.doi.org/10.1080/14660971003780214

Hansen, M. W., Torp, J. E., \& Schaumberg-Müller, H. (2011). What Explains Asian Investments in Denmark? In M. Marinov \& S. Marinova (Eds.), Internationalization of Emerging Economies and Firms, 343-366. Basingstoke, UK: Palgrave Macmillan. http://dx.doi.org/10.1057/9780230363663.0021

Kornai, J. (1979). Resource-Constrained versus Demand-Constrained Systems. Econometrica, 47(4), 801-819. http://dx.doi.org/10.2307/1914132

Kuper, S. (2009). Football abandons the fantasy that it is a business. Financial Times. Retrieved from http://www.ft.com/cms/s/2/fd77a01c-aa07-11de-a3ce-00144feabdc0.html

Lang, M., Grossmann, M., \& Theiler, P. (2011). The sugar daddy's game: How wealthy investors change competition in professional team sports. Journal of Institutional and Theoretical Economics, 167(4), 557-577.

Leach, S., \& Szymanski, S. (2015). Making Money Out of Football. Scottish Journal of Political Economy, 62(1), 2550. http://dx.doi.org/10.1111/sjpe.12065

Madden, P. (2015). Welfare Economics of "Financial Fair Play" in a Sports League With Benefactor Owners. Journal of Sports Economics, 16(2), 159-184. http://dx.doi.org/10.1177/1527002512465759

Mauws, M. K., Mason, D. S., \& Foster, W. M. (2003). Thinking strategically about professional sports. European Sport Management Quarterly, 3(3), 145-164. http://dx.doi.org/10.1080/16184740308721948

Milgrom, P., \& Roberts, J. (1992). Economics, Organization and Management. Englewood Cliffs, NJ: Prentice-Hall. 
Müller, J. C., Lammert, J., \& Hovemann, G. (2012). The Financial Fair Play regulations of UEFA: an adequate concept to ensure the long-term viability and sustainability of European club football. International Journal of Sport Finance, $\quad 7(2), \quad 117-140 . \quad$ Retrieved from http://fitpublishing.com/content/search-keywordsfootball-match-fixing-sports-betting

Nauright, J., \& Ramfjord, J. (2010). Who owns England's game? American professional sporting influences and foreign ownership in the Premier League. Soccer \& Society, 11(4), 428-441. http://dx.doi.org/10.1080/14660971003780321

Nowy, T., Wicker, P., Feiler, S., \& Breuer, C. (2015). Organizational performance of nonprofit and for-profit sport organizations. European Sport Management Quarterly, 1-21. http://dx.doi.org/10.1080/16184742.2014.995691

Peeters, T., \& Szymanski, S. (2014). Financial fair play in European football. Economic Policy, 29(78), 343-390. http://dx.doi.org/10.1111/1468-0327.12031

Picot, A. (1981). Der Beitrag der Theorie der Verfügungsrechte zur ökonomischen Analyse von Unternehmensverfassungen. In K. Bohr, J. Drukarczyk, H.-J. Drumm, \& G. Scherrer (Eds.), Unternehmensverfassung als Problem der Betriebswirtschaftslehre (pp. 153-197). Berlin: Erich Schmidt Verlag.

Ruoss, K. (2009). Allokation von Verfügungsrechten und die Governance von Fußballunternehmen: Eine empirische Analyse unter institutionenökonomischen Aspekten. Organisationsökonomie humaner Dienstleistungen: 24. München / Mering: Rainer Hampp Verlag. http://dx.doi.org/10.1688/9783866185227

Sass, M. (2014). Glory Hunters, Sugar Daddies, and Long-Term Competitive Balance Under UEFA Financial Fair Play. Journal of Sports Economics. Advance online publication. http://dx.doi.org/ 10.1177/1527002514526412.

Smart, D. L., \& Wolfe, R. A. (2000). Examining sustainable competitive advantage in intercollegiate athletics: A resource-based view. Journal of Sport Management, 14(2), 133-153. Retrieved from http://journals.humankinetics.com/jsm-back-issues/JSMVolume14Issue2April/ExaminingSustainableCompetitive AdvantageinIntercollegiateAthleticsAResourceBasedView

Smart, D. L., \& Wolfe, R. A. (2003). The contribution of leadership and human resources to organizational success: An empirical assessment of performance in major league baseball. European Sport Management Quarterly, 3(3), 165188. http://dx.doi.org/10.1080/16184740308721949

Smith, E. (2009). The Sport of Governance - a Study Comparing Swedish Riding Schools. European Sport Management Quarterly, 9(2), 163-186. http://dx.doi.org/10.1080/16184740802571435

Storm, R. K., \& Nielsen, K. (2012). Soft budget constraints in professional football. European Sport Management Quarterly, 12(2), 183-201. http://dx.doi.org/10.1080/16184742.2012.670660

Szymanski, S. (2013). Wages, transfers and the variation of team performance in the English Premier League. In P. Plácido; S. Késenne, S., \& J. García (Eds.), The Econometrics of Sport, 53-62. Cheltenham, UK; Northampton, MA: Edward Elgar. http://dx.doi.org/10.4337/9781781002865.00011

UEFA. (2013). The European Club Licensing Benchmarking Report: Financial Year 2011. Nyon, Switzerland: UEFA. Retrieved from http://www.uefa.org/MultimediaFiles/Download/Tech/uefaorg/General/01/91/61/84/1916184_DOWNLOAD.pdf

Wernerfelt, B. (1984). A resource-based view of the firm. Strategic Management Journal, 5(2), $171-180$. http://dx.doi.org/10.1002/smj.4250050207

Wicker, P., \& Breuer, C. (2011). Scarcity of resources in German non-profit sport clubs. Sport Management Review, 14(2), 188-201. http://dx.doi.org/10.1016/j.smr.2010.09.001

Wilson, R., Plumley, D., \& Ramchandani, G. (2013). The relationship between ownership structure and club performance of football clubs in the English Premier League. Sport, Business and Management. 3(1), 19-36. http://dx.doi.org/10.1108/20426781311316889

Wooldridge, J. M. (2012). Introductory econometrics: A modern approach (5th ed.). Mason, OH: Cengage Learning.

\section{$(\mathrm{cc}) \mathrm{Br}$}

This work is licensed under a Creative Commons Attribution 3.0 License. 